\title{
MATERNAL DEPRIVATION BY EARLY WEANING CAUSESTHE NOCICEPTINTO ALTER THE PALATABILITY AND COOKIE CONSUMPTION
}

\author{
Mayara Matias de Oliveira*1, Paula Luiza Menezes Cruz ${ }^{2}$, Elton Gabriel Fernandes de Brito ${ }^{3}$, \\ Juliana Fonseca Nogueira Alves, Keilla Maria Paz e Silva5, Flávia Regina Gonçalves de Araújo ${ }^{6}$, \\ Taisy Cinthia Ferro Cavalcante ${ }^{7}$, Sandra Lopes de Souza ${ }^{1,7}$ \\ and Amanda Alves Marcelino da Silva ${ }^{3,4}$
}

${ }^{1}$ Postgraduate Nutrition, Federal University of Pernambuco, Recife, Brazil, 50730-120; 2Department of Nutrition, Federal University of Pernambuco, Recife, Brazil 50730-120; ${ }^{3}$ Collegiate of Nursing, Petrolina Campus, University of Pernambuco, Petrolina, Brazil, 56328-900; ${ }^{4}$ Research Group Development, Nutrition, Phytotherapy and Hygiene Petrolina, Brazil,

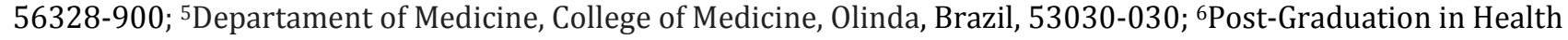
Sciences, Center of Medical Sciences,University of Pernambuco, Recife, Brazil, 52171-011; ${ }^{7}$ Department of Anatomy, Federal University of Pernambuco, Recife, Brazil, 50730-120

\section{ARTICLE INFO}

Article History:

Received $06^{\text {th }}$ February, 2021

Received in revised form

$19^{\text {th }}$ March, 2021

Accepted $22^{\text {nd }}$ April, 2021

Published online $22^{\text {th }}$ May, 2021

Key Words:

Nociceptin/orphanin FQ. NOP

Feeding behavior. Behavior analysis.

*Corresponding autho:

Mayara Matias de Oliveira,

\begin{abstract}
The deprivation of maternal care during the initial development period, as well as interruption of early breastfeeding, promotes changes in eating behavior, however, the underlying neuromodulatory mechanisms have not been fully understood. Studies demonstrate theimportance of the nociceptin receptor (NOP) in modulating the immediate hedonic impact and the hyperphagic effect associated with nociceptin/orphanin FQ (N/OFQ or nociceptin) overexpression. In the current study, experiments have beenperformedto understand the impact of early weaningon the control of hedonic eating behavior and the NOP system's modulatory performance on the resulting phenotype of this injury. Early weaning promotespreference and increasespalatable food consumption, compared to the control group. The NOP receptor antagonist (SB 612111) isable to normalize the palatable food consumption in animals of theearlyweanedgroup, in addition to reducing this consumption in the control group. These results are concordant with the hypothesis that changein hedonic eating behavior, resulting from early weaning are influenced by the NOP system, which, in turn, enhances its potential as a therapeutic target for obesity.
\end{abstract}

Copyright (C) 2021, Mayara Matias de Oliveira et al. This is an open access article distributed under the Creative Commons Attribution License, which permits unrestricted use, distribution, and reproduction in any medium, provided the original work is properly cited.

Citation: Mayara Matias de Oliveira, Paula Luiza Menezes Cruz, Elton Gabriel Fernandes de Brito, Juliana Fonseca Nogueira Alves, Keilla Maria Paz e Silva, Flávia Regina Gonçalves de Araújo, Taisy Cinthia Ferro Cavalcante, Sandra Lopes de Souza and Amanda Alves Marcelino da Silva, 2021. "Maternal deprivation by early weaning causesthe nociceptinto alter the palatability and cookie consumption", International Journal of Development Research, 11, (05), 47011-47017.

\section{INTRODUCTION}

Feeding behavior is defined as a behavior determined by several influences, including the nutritional, demographical, economical, social, cultural, environmental, and psychological aspects of an individual or society [1]. In mammals, breastfeeding is the first determinant of eating behavior, asthe chmother is the nutritional source forthe offspring [2]. Furthermore, this process guarantees the start of socialization between individuals, adding a cultural composition of cognition and changes, whichwill have an influence on the psychological-social construction, on the child's education, and on the future adult. The biological complexity of the mother-offspring relationshipgoes beyond supplying the nutritional needs. The mother provides the essential thermal, somatosensory, olfactory, visual, and auditory stimulation, during part of the postnatal development [3].
The environment createsimpressions, both in animals and humans, whichwill influence the neurobiological and psychologicalfactors throughout life [4,5]. Stress factors, including maternal separation, produce behaviors characteristic of anxiety and affective disorders in the animal [6]. The presence of immediate consequences, as well as, early weaning and its long-term effects, particularlyonthe behavioral and molecular patterns of control over eating behavior, have not yet been fully characterized [7]. Therefore, it is worth highlighting the opioidergic system that is widely distributed in the neuronal circuitry, involved in the sensory, metabolic, and integrative guidelines of eating behavior [8]. Implanted in the opioidergic family is the nociceptin / orphanin FQ-NOP receptor system, which has high expression in the central nervous system, especially in the limbic system [9]. Thepresence of the NOP systemin the cerebral cortex and in the dopaminergic and serotonergic nucleous, transmits it to the 
countless centrally-induced actions, such as, pain transmission, motor control, stress response, learning, memory, dependence,drug abusereward, and food intake [10]. Evidence points to the participation of the NOP system in controlling food intake in rodents, exerting an orexigeniceffect $[11,10]$. The intracerebroventricular (ICV) administration of nociceptin / orphanin FQ in rats was able to promote an increase in the food consumption of these animals [11]. Bewicket al.showed that treatment withnociceptinstimulated an increase in Agouti-Related Protein(AgRP) and a decrease in Cocaineand Amphetamine-Regulated Transcript(CART) release [12]. It is known that AgRP is an orexigenic peptide that competes with the stimulating hormone of $\alpha$-melanocytes $(\alpha-\mathrm{MSH})$ for melanocortin receptors, while the CART exerts an inhibitory effect on food intake [13]. Statnicket al. demonstrated that the administration of an NOP antagonist (LY2940094) was able to reduce food consumption and weight gain in rodents [14]. Injuries during the early stages of development induce changes in feeding behavior.Thisassociation isa reflection of the compensatory mechanisms for neutrotransmission involved in the regulation of this behavior. Taking these data into account, we hypothesize that the nociceptin system is dysregulatedin animals submitted to early weaning, with increased consumption and the search for food reward.

\section{MATERIALS AND METHODS}

Animals: Female Wistar rats (200-250g of body weight; $\mathrm{n}=16$ ) were obtained from the Breeding Animal Hospital of the Department of Nutrition inthe Federal University of Pernambuco. Pregnant, rats were kept individually in cages, in facilities underconditions of constant temperature $\left(20^{\circ} \mathrm{C}\right)$, luminosity $(12-12$ hour cycle, lights on at 6 p.m.), and free access to water and commercial laboratory standard diet of vivarium (Presence ${ }^{\circledR}$ ). The litters were culled to eightpuppies per mother. Animal care compliedwith the Animal Research: Reporting of In Vivo Experiments(ARRIVE) guidelines and followed the National Institutes of Health guide for the Care and Use of Laboratory Animals (NIH Publications No. 8023, revised), and it wasconducted in agreement withthe National Council of Control of Animal Experimentation (CONCEA), with the approval of the Animal Ethical Committee of the Federal University of Pernambuco ( $N$ : 0030/2017). The experimental groups were designed according to the period of weaning, by separation from the mother. The regular weaning group was composed of pups weaned at D30. Theselitters were kept with the dams until postnatal day30, and then they were separated from the dams, and allocated cages, in groups of two per cage. The early weaning group comprised of pups weaned at D15. Onpostnatal day15, theselitters were separated from the dams and kept together until 30 days of age, following whichthey were separated into cages, of two rats per cage. During this period (15-30 days), the early weaning litters had access to crushed commercial laboratory chow froma recipient on the cage floor, and commercial laboratory standard diet from acage dispenser, and regular weaning litters had access to breastmilk from the dam and commercial laboratory standard diet available in a cage dispenser. At least threedays before the startof the tests, the rats were individually separated into cages.

Body Weight Evaluation: Body weight was measured on days 0, 15, $30,60,90$, and 120 postnatally. The rats were individually located in cages that had their body mass accessed during the dark phase and were immediately returned to their home cages. For body weight measurements, an electronic scale with a capacity of $4 \mathrm{~kg}$ and a sensitivity of $0.1 \mathrm{~g}$ (Marte, model S-4000, São Paulo-SP, Brazil) was used.

Palatable Food Intake and Pattern Diet: Apalatable food (Cookie de chocolate, $4.37 \mathrm{Kcal} / \mathrm{g}$ ) and standard vivarium diet intake for 24 hours was given to animals for60, 90, and 120 days of life. On different days, during thistime, they had access to chocolate cookies or commercial laboratory standard diet available in cage dispensers. The difference between the food offered and thatremainingin the cage dispenser was considered as food intake. The consumption was measured after 30 minutes, and 1, 2, 4, 6, 12, and 24 hours.

Food Preference Test: At 120 days, the food preference test was performed. To measure thefood preference, the consumption of palatable food (Cookie de chocolate, $4.37 \mathrm{Kcal} / \mathrm{g}$ ) was compared withthe consumption of the standard diet (Presence ${ }^{\mathbb{B}}$ ). During thistime they had access to both kind of foods, at same time, for a period of 24 hours in thecage.

Drugs: To investigate the performance of the nociceptin system, the NOP receptor antagonist, SB-612111 (SB-612111 hydrochloride, Sigma-Aldrich, USA), was used. The drug was dissolved and diluted in sterile $0.9 \%$ saline and applied in a volume of $0.01 \mathrm{ml} / \mathrm{g}$, acute dose of $10 \mathrm{mg} / \mathrm{kg}$, intraperitoneally [16].

Palatable Food Intake Compared to Pharmacological Manipulation with the NOP Receptor Antagonist : The animals, at the age of 35 days, received SB-612111 (10mg / kg of body weight) or saline solution $(\mathrm{NaCl} 0.9 \%)$ in a volume of $10 \mathrm{ml} / \mathrm{kg}$ inan acute dose of $10 \mathrm{mg} / \mathrm{kg}$, intraperitoneally. Thirty minutes after the injection, palatable food (Cookie Chocolate, $4.37 \mathrm{kcal} / \mathrm{g}$ )was made available in a known quantity. After thirty minutes of the offer, the food was removed and weighed to obtain the consumption - the difference between the quantity offered and the quantity rejected.

Runway Task Incentive: At 60 days of age, the animals were submitted to the Runway Task Incentive to study "Learning" and "Wanting" $[17,18]$, after fourhours of deprivation of the feed. This test consistedof a behavioral paradigm, which generatedthelearning acquisition curves, as well as the speed and trajectory traveled, which expressed the animal's motivation toward the reward stimulus. The training sessions were conducted during 11 sessions on alternate days (22 days), each session lasting 5 minutes. In the first three sessions, the rats were placed directly in the target box (with the doors closed) for 5 minutes, with access to the reward. The animals hadadjusted to chocolate cookies in the first threesessions. In the fourthtraining session, the initial box was located $15 \mathrm{~cm}$ from the target box. The animal stayed in the starter box for 30 seconds with the door closed, then the door was opened and the animal could proceed by running through the center. If the animal did not leave the initial box in 3 minutes, it was gently moved to the target box. In the fifth session, the initial box was moved $30 \mathrm{~cm}$ away from the target box; in the sixthsession, $60 \mathrm{~cm} ; 75 \mathrm{~cm}$ in the seventhsession; $90 \mathrm{~cm}$ in the eighthsession; $120 \mathrm{~cm}$ in the ninth session; and $140 \mathrm{~cm}$ in the tenthand eleventhsessions. The complete task was calculated for each session, divided by the latency time of reaction to the target box and the length of each day. Thus, the speed of completion of each session was obtained. The departure from the initial box and the entry into the target box were recorded when the four legs of the animal were inside the compartments. The test was completed when the animal entered the target box and started consuming the reward in 30 seconds. Thus, sessions 12 and / or 13 could be conducted.

Taste Reactivity Test: The test of reactivity was carried out at 90 days of age, to study the "Liking" [18]. To perform this test, the animal was placed in an arena $(25 \mathrm{~cm} \times 25 \mathrm{cmx} 20 \mathrm{~cm})$, with transparent floor and walls. To evaluate the response,sweet and bitter flavors were used, respectively; $1 \mathrm{ml}$ of sucrose solution at $30 \%$ or quinine solution $\left(\mathrm{C} 20 \mathrm{H} 24 \mathrm{~N} 2 \mathrm{O} 2 \cdot \mathrm{HCl} \cdot 2 \mathrm{H} 2 \mathrm{O}\right.$, Sigma $\left.^{\circledR}\right)$ at $0.3 \mathrm{M}$. A video camera (Sony Handycam DCR-DVD650, with nightshot function) was placed under the transparent floor to film the spontaneous facial and bodily reactions that occurred during and after the voluntary intake of sucrose or quinine. The animals were allowed to get used to the test arena for 2.5 minutes before it started. In each test, sucrose or quinine solutions wereplaced in the left corner of the arena and directly on the floor [19]. The animals were allowed to ingest the solutions for 2.5 minutes, during which their behavior was filmed for further analysis. To determine the affective reactions of the animals, positive or hedonic reactions were considered: Rhythmic protrusions of the tongue, lateral protrusion of the tongue, and licking the paws; and as negative or aversive reactions: yawning, shaking the head, cleaning the face, "wagging" with the front legs, rubbing the 
chin. The analyses between one type of solution and another were carried out with a minimum interval of 48 hours.

Statistical Analysis: Statistical analysis was performed in a descriptive manner with the aid of a GraphPad Prism 5, version 7, San Diego-CA, USA. Data were expressed as mean \pm standard error of the mean (SEM). For the 12- and 24-hour food preference test, oneway Analysis of Variance (ANOVA) was used. Student's ttest was used to test the reactivity to taste. For comparingthedifferent groupsof body weight, food consumption, and evaluation of the effect of the NOP antagonist on the consumption of cookies, theTwo-Way ANOVA was used. When the ANOVA revealed a significant difference, the Bonferroni test was used for multiple comparisons. For all analyses, significance was considered to be $p<0.05$.

\section{RESULTS}

Body Weight: The evaluation of body weight during days $0,15,30$, $60,90,120$ days did not present statistical differences in the analyzed groups D15 $(\mathrm{n}=29)$ andD30 $(\mathrm{n}=29)$. There was no influence of early weaning $\left(\mathrm{F}_{(1,336)}=4.498, p=0.0347\right)$ (Figure 1).

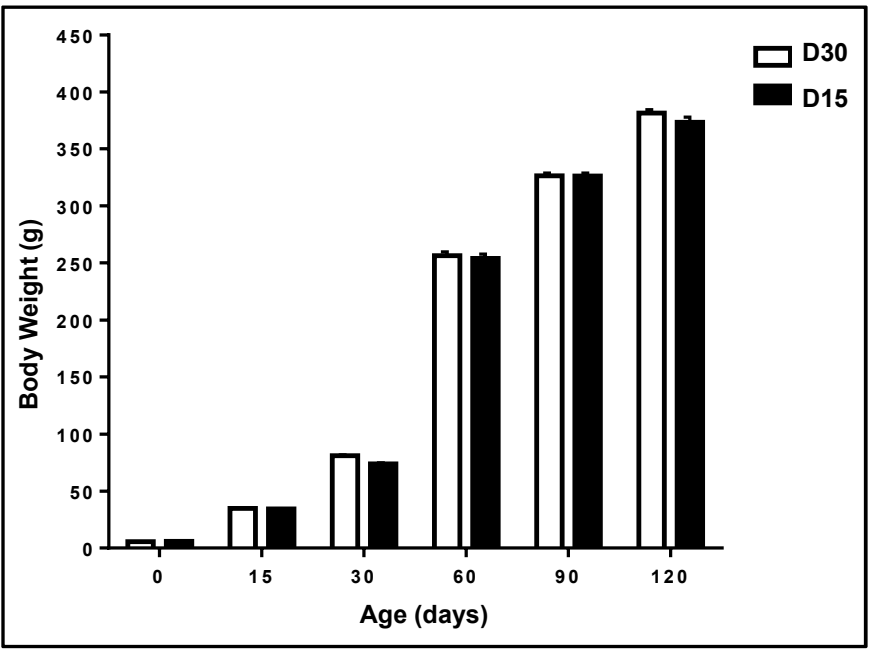

Figure 1. Body weight evolution of males submitted to early weaning. Two-way ANOVA was used followed by Bonferroni test, ${ }^{*} p<0.05$. Data presented as mean \pm SEM. D30, $n=29$; D15, $\mathbf{n}=\mathbf{2 9}$

Food Intakeat 60, 90, and 120 days: The food intake test showed no difference in the consumption of a control diet (Labine, Presence ${ }^{\circledR}$, Campinas-SP) between the groups (D15, $\mathrm{n}=16 ; \mathrm{D} 30, \mathrm{n}=17)$ at any of the ages evaluated; $60\left[\left(\mathrm{~F}_{(1,161)}=0.0458\right), p=0.8308\right] ; 90\left[\left(\mathrm{~F}_{(1,203)}\right.\right.$ $=8,754, p=0.9432], 120$ days $\left[\left(\mathrm{F}_{(1,203)}=0.3495, p=0.5551\right]\right.$. (Figure 2). Regarding the palatable food intake (Cookies Chocolate Bauducco $\left.{ }^{\circledR}\right)$, it was observed that theearly weaning group $(n=16)$ consumed more cookies compared to the control group $(\mathrm{n}=17)$ at all times, at age 60 days $\left[\left(\mathrm{F}_{(1,217)}=116.1, p<0.0001\right)\right]$.(Figure 3a) $((30 \mathrm{~min}: \mathrm{D} 15=5.88 \pm 0.58 ; \mathrm{D} 30=2.19 \pm 0.43 ; p<0.0001),(1 \mathrm{~h}: \mathrm{D} 15$ $=9.37 \pm 0.72 ; \mathrm{D} 30=4.17 \pm 0.60),(2 \mathrm{~h}: \mathrm{D} 15=13.33 \pm 0.80 ; \mathrm{D} 30=7.49$ $\pm 0.84 ; p<0.0001),(4 \mathrm{~h}: \mathrm{D} 15=17.80 \pm 0.87 ; \mathrm{D} 30=12.23 \pm 1.97$; $p<0.0001),(6 \mathrm{~h}: \mathrm{D} 15=22.40 \pm 1.07 ; \mathrm{D} 30=15.32 \pm 1.10 ; p<0.0001)$, $(12 \mathrm{~h}: \mathrm{D} 15=27.08 \pm 0.92 ; \mathrm{D} 30=19.50 \pm 1.45 p<0.0001),(24 \mathrm{~h}: \mathrm{D} 15$ $=37.30 \pm 0.67$; $\mathrm{D} 30=33.11 \pm 1.66 ; p<0,0001))$.At 90 days $\left(\mathrm{F}_{(1,203)}=\right.$ $0.2618, p=0.6095)$ was significant only in the consumption of 24 hours $(\mathrm{D} 15=38.67 \pm 1.11$; D30 $=33.72 \pm 1.24 ; p<0.0001)$ (Figure $3 \mathrm{~b})$. The same behavior was not observed at 120 days, as there was no significance in any of the analyzed intervals $\left(\mathrm{F}_{(1,203)}=0.6991\right.$, $p=0.4041$ ).(Figure 3c).

Food Preference Test: The food preference test showed greater palatable food intake in both groups at $12 \mathrm{~h}-\mathrm{F}_{(3,60)}=39.97, p<0.0001$, presenting the following results:(D30 control diet $12 \mathrm{~h}=5.19 \pm 0.81, \mathrm{n}$ $=16 ;$ D30 cookie $12 \mathrm{~h}=15.18 \pm 1.26 ; \mathrm{n}=16),(\mathrm{D} 15$ control diet $12 \mathrm{~h}$
$=4.67 \pm 0.89, \mathrm{n}=16 ; \mathrm{D} 15$ cookie $12 \mathrm{~h}=16.71 \pm 1.12 ; \mathrm{n}=16)$. The $24 \mathrm{~h}$ preference analysis revealed $\mathrm{F}_{(3,60)}=155.7, p<0.0001$,presenting the following results: (D30 control diet $24 \mathrm{~h}=8.71 \pm 1.01, \mathrm{n}=16$; D30 cookie24 h $30.24 \pm 1.85, \mathrm{n}=16)$, (D15 control diet $24 \mathrm{~h}=6.81 \pm 0.89$, $\mathrm{n}=16$; D15 cookie $24 \mathrm{~h}=35.56 \pm 0.56, \mathrm{n}=16$ ). However, the difference in consumption of palatable food between the D30 and D15 groups $(p<0.05)$ was observed only in a24-hour time span (Figure 4).
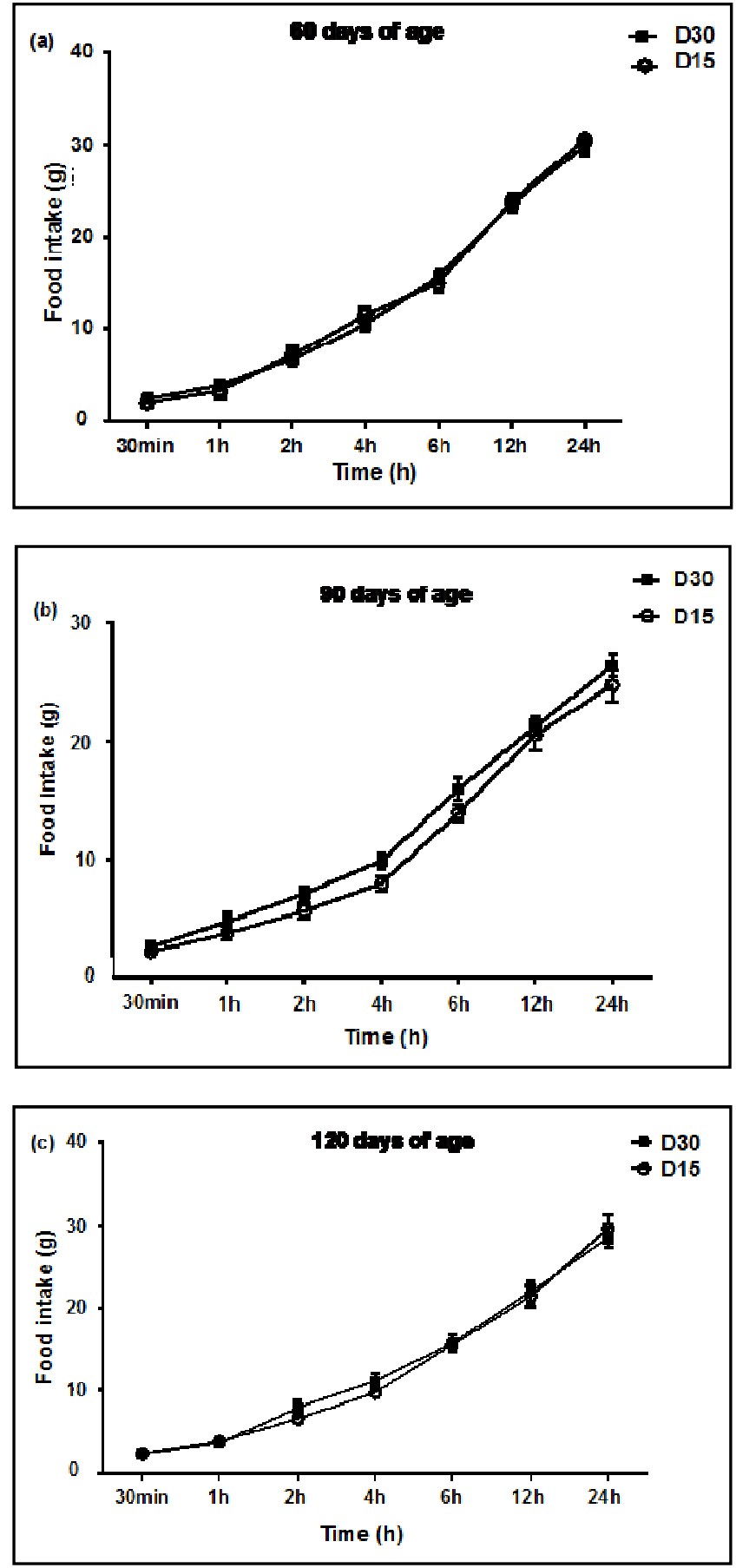

Figure 2. Effect of early weaning on food intake pattern, vivarium diet (LabinePresence ${ }^{\mathbb{B}}$ ) at (a) 60, (b) 90, and (c) 120 days of life. Two-way ANOVA was used followed by the Bonferroni test, $p$ $<0.05$. Data presented as mean \pm SEM.; D30, $n=17, D 15, n=16$

Consumption of palatable food compared to pharmacological manipulation with the NOP receptor antagonist (SB-612111) Blocking the NOP receptor reduced the consumption of palatable food from both $\left(\mathrm{F}_{(1,20)}=23.53, p<0.0001\right)$. In the control group (D30Vehicle=13,69 $\pm 1,50, \mathrm{n}=7$; D30 SB-612111 =6,47 $\pm 1,44, \mathrm{n}=5)$, and in the early weaning group (D1-Vehicle $=16,16 \pm 1,54, \mathrm{n}=7$; D15 SB-612111 $=6,90 \pm 2,32, n=5$ ). 

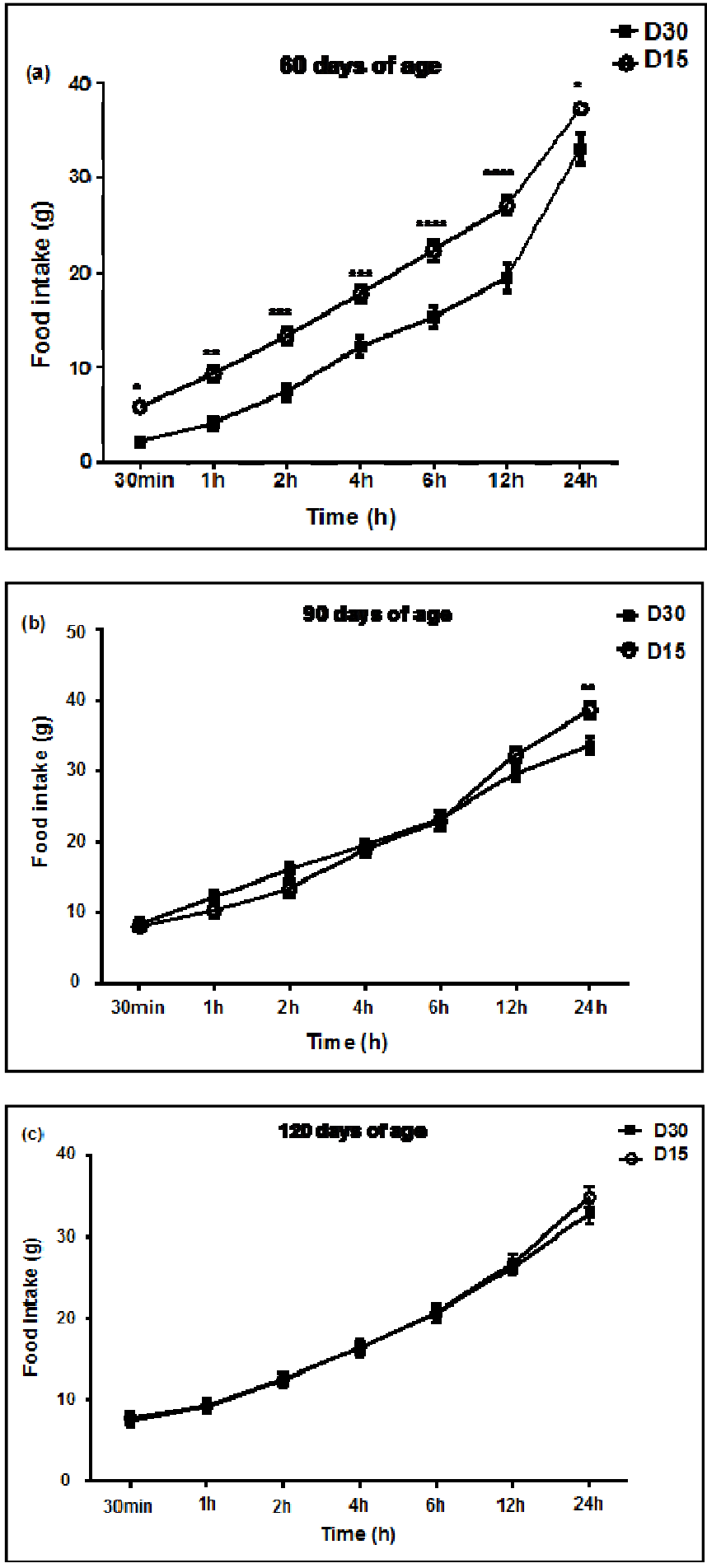

Figure 3. Effect of early weaning on palatable food intake at (a) 60, (b) 90, and (c) 120 days of life. Two-way ANOVA was used followed by Bonferroni test, * $p<0.05$. Data presented as mean \pm SEM.; D30, $n=17, \mathrm{D} 15, \mathrm{n}=16$

The NOP receptor antagonist reduced $53 \%$ of cookie consumption in the control group and $57 \%$ in animals submitted to early weaning. (Figure 5).

Runway Task Incentive: There were no differences in the search for palatable food (Wanting) in the early weaning group, $\left(\mathrm{F}_{(1,222)}=2.027\right.$, $p=0.1560$ ) (Pre-exposure D15: S4 $=0.14 \pm 0.02 ; \mathrm{S} 5=0.29 \pm 0.04 ; \mathrm{S} 6$ $=0.59 \pm 0.10 ; \mathrm{n}=15$; Incentive to learning D15: $\mathrm{S} 7=0.87 \pm 0.12 ; \mathrm{S} 8$ : $1.39 \pm 0.17 ; \mathrm{S} 9=1.82 \pm 0.24 ; \mathrm{n}=15$; Trained D15: $\mathrm{S} 10=2,58 \pm$ 0.28 ; $\mathrm{S} 11=2.46 \pm 0.29 ; \mathrm{n}=15)$ in relation to its control (D30 preexposure: $\mathrm{S} 4=0.11 \pm 0.02$; $\mathrm{S} 5=0.29 \pm 0,05$; $\mathrm{S} 6=0.48 \pm 0.11 ; \mathrm{n}=15$; Incentive to learning D30: $\mathrm{S} 7=0.77 \pm 0.11 ; \mathrm{S} 8: 1.12 \pm 0.15 ; \mathrm{S} 9=1.55$ $\pm 0.20 ; \mathrm{n}=15 ;$ Trained D30: $\mathrm{S} 10=2.38 \pm 0.20 ; \mathrm{S} 11=2.52 \pm 0.16 ; \mathrm{n}$ $=15$ ) (Figure 6).

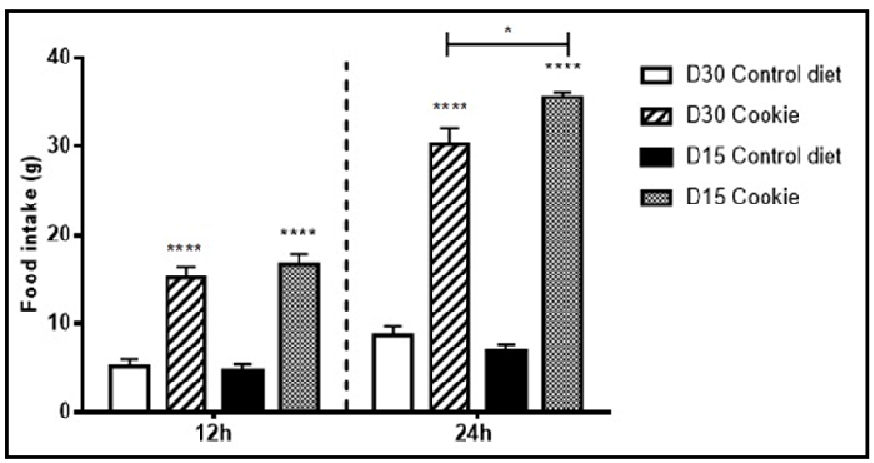

Figure 4. Maternal deprivation effect by early weaning of food preference. One-way ANOVA, * $p<0.05, * * * p<0.0001$. Data presented as mean \pm SEM.; D30, $n=16, D 15, n=16$

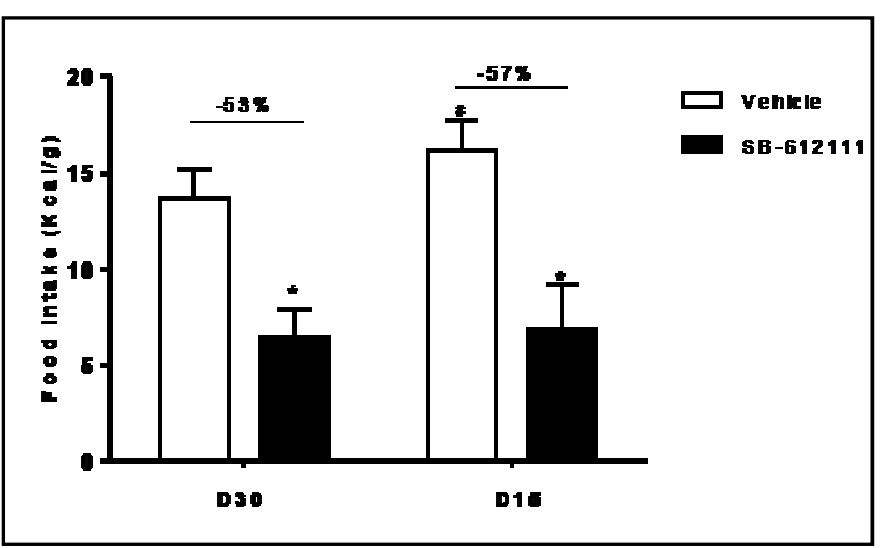

Figure 5. NOP receptor antagonist effect on cookie intake in males submitted to maternal deprivation by early weaning (Kcal). Data were represented as mean- \pm standard error. Data were analyzed with two-way ANOVA. * $p<0.0001$, intra-group comparison NOP receptor antagonist effect on palatable food intake. D30, $n=7, D 15, n=5$

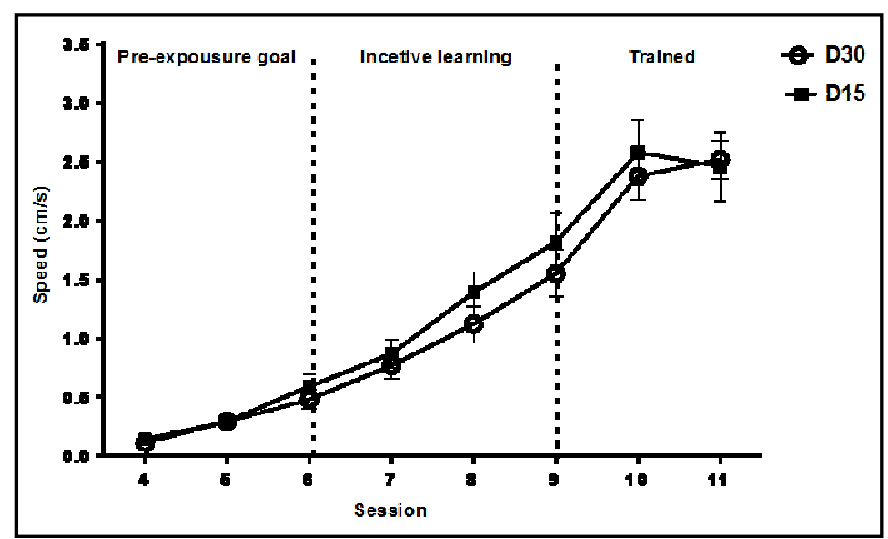

Figure 6. Test food motivation in males submitted to the maternal deprivation effect by early weaning. Data presented as mean \pm SEM. Two-way ANOVA, was used followed by the Bonferroni test. Groups: D30, $n=15, D 15, n=15$

Taste Reactivity Test: Regarding the early weaning effect on taste reactivity, animals of the early weaning group(D15 Sucrose $=48.28 \pm$ $1.08, \mathrm{n}=9$ ) had a shorter reaction time to sucrose when compared to control animals (D30-Sucrose $=52.68 \pm 0.87, \mathrm{n}=10 ; p=0.0052)$ (Figure 7a). Likewise, the weaning group (D15 Quinine $=35.76 \pm$ $1.22, \mathrm{n}=10$ ) showed shorter reactivity time to quinine, when compared to the control group (D30-Quinine $=41.98 \pm 0.62, \mathrm{n}=11 ; p$ $=0.0002)$ (Figure $7 b)$. 
(a)

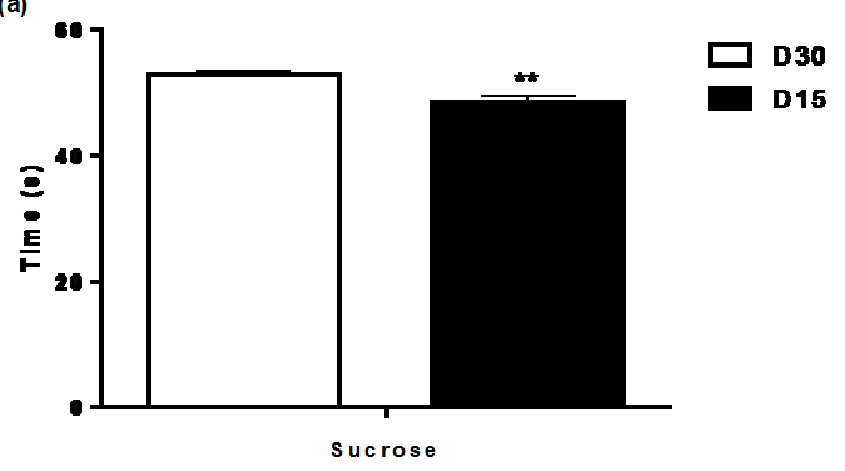

(b)

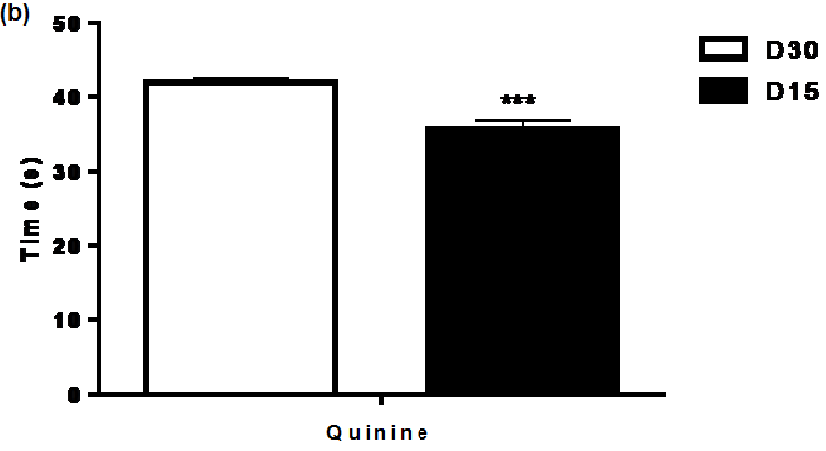

Figure 7. Reactivity test the taste of males submitted to maternal deprivation by early weaning. (a) Sucrose; (b) Quinine. Student $t$ test was used, $* * * p<0.001$. The data were expressed as mean and standard error. Groups: D30, $n=11, D 15, n=10$

\section{DISCUSSION}

The feeding behavior is especially susceptible to environmental factors in the lactation period, and is considered a critical stage in the neurohormonal patterns in offspring maturation[20]. Eatingis not a simple behavior. Feedingouserlves requires a set of tasks to be performed by the central and peripheral nervous system to coordinate the beginning of the meal, food acquisition, acquired food consumption, and the end of the meal. Most of these tasks are behaviors learned during and after weaning [21]. Early weaning is an experimental model consisting of abrupt and early interruption of the lactation in rats [15].Thus, rats are deprived of two important factors in modulating proper development: Maternal care and lactation.Studies revealed that early weaning is associated with a retarded satiety point, increased weight gain, hyperleptinemia, hyperphagia, and hypertrophy of the visceral and subcutaneous adipocytes in adulthood, when compared to animals that were naturally weaned [11,22]. Early weaning is a model used to imitate social behavior, in which breastfeeding is neglected, resulting in parameters related to growth, physiology,as also influencing behavior [23]. In this respect, body weight evolution is one of the first aspects to be analyzed. In body weight evaluation, nodifferenceswere observed between animals weaned early and the controls. Oliveira et al. demonstrated an association between early weaning and low weight right after weaning, followed by weight recovery from the twentieth day of life[15]. Other studies, which used the same weaning protocol, obtained similar findings, suggesting that the effect was caused by the abrupt interruption of breastfeeding and its concomitant substitution by solid food intake, with a different nutritional composition from breast milk [22,23]. Individuals exposed to nutritional injuries and/or maternal contact deprivation in the early stages of life have a greater tendency to consume palatable foods as adults $[6,18,28]$. The food intake analysis in a standard diet showed that, at the ages evaluated, both groups had similar consumption. However, with respect topalatable food, it was observed that animals submitted to early weaning had higher consumption at ages 60 and 90 days of life, when compared to the control animals. These results are in agreement with other findings from our research group, which showed an increase in the palatable food intake, as well as retardation inthe satiety point in the adult life of animals that were weaned early [15]. Evidence designates that eating rhythms patterns can be modulated by maternal behavior [24]. Animals weaned early have changes in feeding periods during the light and dark phases [15]. Interestingly, in the palatable food evaluation at 90 days,we saw that the cookie intake was higher in the weaned group only at 24 hours. This behavioral pattern was also seen in the food preference evaluation, where we observed that, although both groups preferred the palatable food, the animalsweanedearly consumed more cookies compared to the control group at 24 hours. The association of these findings suggestedthe possibility of the influencing effects of early weaning on food rhythmicity in the face of a palatable stimulus. The main factors that influence food choices arethe perception of food, and particularly, its taste. Gustatory perception is important to guarantee nutrient acquisition and avoid toxic substanceingestion[25]. Within the sensory system, taste is the only one that has an innate association with the reward and aversion mechanisms,in response to the quality of the substances ingested [26]. The capacity / intensity ofeach individual to noticedifferent tastes is called gustatory sensitivity, which varies between individuals, and it is a leading factor in food choices and nutritional status [27]. Liking, Wanting, and Learning are pillars on which hedonic eating behavior rests. The runway task incentive is an experimental test that evaluates the 'wanting' and 'learning' components after food deprivation [28]. The analysis of these components shows that weaning group behavior is similar to the control group. Liking is aconscious reaction related to cognitive mechanisms, whose main stimulus is the motivational value of taste or palatability [29]. Information about palatability is processed in different receptors distributed in the lingual papillae. The bitter taste is a taste for which the reaction is innately aversive, which appears as a defense to potentially avoid toxic food ingestion[25].

The insular gustatory cortex is capable of responding to two neuronal populations of taste: Type 1is related to the sensory perception of flavors, without defining the reward value, and the other neuronal population,Type 2, shows the excitatory responses to the palatable stimulus (sucrose), andis inhibitory in response to the aversive stimulus (quinine) [29]. The response of the hedonic basic flavorsis subject to fetal and perinatal "programming" [30]. In our study, the taste reactivity test revealed that animals submitted to early weaning have sensitivity to the aversive substance and decreased sweet taste perception. This same pattern is found in experimental models of obesity and overweight, whose decreasedpleasure reactions are compensated with anincrease in energy consumption, in order to achieve the food reward patterns [31]. In addition, early weaning by maternal separation, or by inhibition of lactation through maternal treatment with a prolactin inhibitor, is associated with neonatal innutrition [15,22], which is also pointedout to be apredictorof damage to information on taste perception and hedonic responses [32]. These associatedfindingssuggest the existence of a possible damage mechanism to the liking caused by changes resulting from early weaning. 'Liking' is the result of the food hedonic impact and its stimulus is generated especially viathe opiodergic route. Experimental analyses show that application of nonspecific opioidergic receptor antagonists decrease the palatable food intake, even when administered in low doses, insufficient to modify the standard diet consumption[33]. Alternatively, opioid receptor agonists are particularly effective in increasing the palatable diet intake[34]. Besides, opioids also affect the macronutrient selection. Generally, rats treated with opiates tend to prefer a high-fat diet, when diets high in carbohydrates and fats are presented simultaneously [35]. However, it should be noted that initial preference for a particular macronutrient drives the effect of theopiates to theselectionof the macronutrient. In laboratory animals, morphine injections increased carbohydrate intake in mice that preferred carbohydrates, while increasing the intake of high-fat diets in animals that preferred fat [36]. The opioidergic neurophysiologyof peculiarites in eating behavior are even more complex when we take into account its youngest component described: The nociceptin system. Incorporated in the opiodergic system and with action 
mechanisms that are still poorly understood, the nociceptin modulates several physiological functions including depression, stress, anxiety, food, locomotor activity, body temperature, substancesof abuse, memory, and pain [10]. Some studies highlight the role of this system in the eating behavior control.It'saction involves neurotransmitters classically related to hedonic control, such as, dopamine and serotonin $[37,38,39]$.Studies related to the involvement of nociceptin in eating behavior, show that its central administration induces hyperphagia and decreasesthe aversive response to food [16,38].The NOP antagonist was able to decrease the consumption of palatable food in both the evaluated groups, with the early weaned group being slightly more sensitive to this effect. Similar results were observed by Hardaway (2016), who reported decreased intake of high-fat foods after treatment with an NOP antagonist (SB 612111) in animal modelswith eating compulsion [16]. Our findings related to consumption and preference for palatable foods have beenadded to the evidence reported in the scienceliterature, suggesting that changes triggered by early weaning in hedonic eating behavior are associated with dysfunction of the nociceptin system. Early weaning, characterized as an injury, affects functional mechanisms thatcontrol eating behavior, resulting in long-term detectable changes in the adult organism $[40,41]$. This is the first study that has investigated the involvement of nociceptin and its receptor in hedonic eating behavior changes resulting from early weaning. Furthermore, the analyses carried out provide an interesting insight into the central mechanisms that mitigate the hedonic control of eating behavior, highlighting NOP antagonism as an attractive target for the treatment of eating compulsion and obesity. It is important to notice that further studies, including molecular analyses, are needed to fully understand the hypophagic action of NOP antagonist mechanism. Our results demonstrate that early weaning induces increased consumption of palatable foods and that this consumption pattern is normalized after blocking the NOP receptor. Thus, we can suggest that early weaning causes a dysfunction of the N/ OFQ system, resulting in changes in the consumption of palatable foods, response to acute stress, food preferences, and in the palatability mechanisms of hedonic eating behavior.

Acknowledgements: Foundation for Science and Technology of the State of Pernambuco (FACEPE) and National Council for Scientific and Technological Development $(\mathrm{CNPq})$. M.M.O. received a Fellowship from FACEPE (grant \#IBPG-1298-4.05/16).

\section{REFERENCES}

Aguggia JP, Suárez MM, Rivarola MA. (2013) Early maternal separation: Neurobehavioral consequences in mother rats. Behavioural Brain Research. 248. pp. 25-31.

Ayres C, Agranonik M, Portella AK, Filion F, Johnston CC, Silveira PP. (2012) Intrauterine Growth Restriction and the Fetal Programming of the Hedonic Response to Sweet Taste in Newborn Infants. International Journal of Pediatrics. 2012. pp. $1-5$.

Barker DJP. (1997) The fetal origins of coronary heart disease. European Heart Journal .18(6). pp. 883-884.

Bellisle F, Drewnowski A, Anderson GH, Westerterp-Plantenga M, Martin CK. (2012) Sweetness, Satiation, and Satiety. The Journal of Nutrition 142. pp. 1149S-1154S.

Bewick GA, Dhillo WS, Darch SJ, Murphy KG, Gardiner JV, Jethwa PH, Kong WM, Ghatei MA, Bloom SR. (2005) Hypothalamic Cocaine- and Amphetamine-Regulated Transcript (CART) and Agouti-Related Protein (AgRP) Neurons Coexpress the NOP1 Receptor and Nociceptin Alters CART and AgRP Release. Endocrinology. 146. pp. 3526-3534.

Caldji C, Diorio J, Meaney MJ. (2000) Variations in maternal care in infancy regulate the development of stress reactivity. Biological Psychiatry. 48. pp. 1164-1174.

Chandrashekar J, Hoon MA, Ryba NJ, Zuker CS. (2006) The receptors and cells for mammalian taste. Nature. 444. pp. 288 294. da Silva AA, Oliveira MM, Cavalcante TC, do Amaral Almeida LC, de Souza JA, da Silva MC, de Souza SL. (2016) Low protein diet during gestation and lactation increases food reward seeking but does not modify sucrose taste reactivity in adult female rats. Int J Dev Neurosci 49. pp. 50-59.

da Silva MC, de Souza JA, dos Santos LO et al. (2014) Effects of maternal separation on the dietary preference and behavioral satiety sequence in rats. Journal of Developmental Origins of Health and Disease. 5. pp. 219-228.

Ferenczi S, Núñez C, Pintér-Kübler B, Földes A, Martín F, Márkus VL, Milanés MV, Kovács KJ. (2010) Changes in metabolicrelated variables during chronic morphine treatment. Neurochem Int. 57. pp. 323-353.

Gluckman PD, Hanson MA. (2004) Developmental Origins of Disease Paradigm: A Mechanistic and Evolutionary Perspective. Pediatric Research. 56. pp. 311-317.

Gosnell BA, Krahn DD, Majchrzak MJ. (1990) The effects of morphine on diet selection are dependent upon baseline diet preferences. Pharmacology Biochemistry and Behavior. 37. pp. 207-212.

Haghighi A, Melka MG, Bernard M, Abrahamowicz M, Leonard GT, Richer L, Perron M, Veillette S, Xu CJ, Greenwood CM, Dias A, El-Sohemy A, Gaudet D, Paus T, Pausova Z. (2014) Opioid receptor mu 1 gene, fat intake and obesity in adolescence. Molecular Psychiatry. 19. pp. 63-68.

Hardaway JA, Jensen J, Kim M, Mazzone CM, Sugam JA, Diberto JF, Lowery-Gionta EG, Hwa LS, Pleil KE, Bulik CM, Kash TL. (2016) Nociceptin receptor antagonist SB 612111 decreases high fat diet binge eating. Behavioural Brain Research. 307. pp. $25-34$.

Kabir A, Miah S, Islam A. (2018) Factors influencing eating behavior and dietary intake among resident students in a public university in Bangladesh: A qualitative study. PLOS ONE. 13. pp. e0198801-e0198801.

Kalra SP, Dube MG, Pu S, Xu B, Horvath TL, Kalra PS. (1999) Interacting appetite-regulating pathways in the hypothalamic regulation of body weight. Endocr Rev. 20. pp. 68-100.

Kikusui T, Isaka Y, Mori Y. (2005) Early weaning deprives mouse pups of maternal care and decreases their maternal behavior in adulthood. Behavioural Brain Research .162. pp. 200-206.

Koob GF. (2008) A Role for Brain Stress Systems in Addiction. Neuron 59. pp. 11-34.

L. M'Rabet, A. P. Vos, G. Boehm, J. Garssen. (2008) Breast-Feeding and Its Role in Early Development of the Immune System in Infants: Consequences for Health Later in Life. The Journal of Nutrition 138(9). pp. 1782S-1790S.

Levin R, Stern JM. (1975) Maternal influences on ontogeny of suckling and feeding rhythms in the rat. Journal of Comparative and Physiological Psychology. 89. pp. 711-721.

Levine AS, Billington CJ. (1997) Why Do We Eat? A Neural Systems Approach. Annual Review of Nutrition. 17. pp. 597-619.

Lima NS, Moura EG, Franco JG, Pinheiro CR, Pazos-Moura CC, Cabanelas A, Carlos AS, Nascimento-Saba CC, de Oliveira E, Lisboa PC. (2012) Developmental Plasticity of Endocrine Disorders in Obesity Model Primed by Early Weaning in Dams. Hormone and Metabolic Research. 45. pp. 22-30.

Lü N, Han M, Yang ZL, Wang YQ, Wu GC, Zhang YQ. (2010) Nociceptin/Orphanin FQ in PAG modulates the release of amino acids, serotonin and norepinephrine in the rostral ventromedial medulla and spinal cord in rats. Pain. 148. pp. 414-439.

Oliveira Ldos S, da Silva LP, da Silva AI, Magalhães CP, de Souza SL, de Castro RM. (2011) Effects of early weaning on the circadian rhythm and behavioral satiety sequence in rats. Behav Processes. 86. pp. 119-143.

Olszewski PK, Grace MK, Fard SS, Le Grevès M, Klockars A, Massi M, Schiöth HB, Levine AS. (2010) Central nociceptin/orphanin FQ system elevates food consumption by both increasing energy intake and reducing aversive responsiveness. Am J Physiol Regul Integr Comp Physiol. 299. pp. R655-R663.

Olszewski PK, Grace MK, Sanders JB, Billington CJ, Levine AS. (2002) Effect of nociceptin/orphanin FQ on food intake in 
rats that differ in diet preference. Pharmacol Biochem Behav. 73. pp. 529-564.

Peciña S, Cagniard B, Berridge KC, Aldridge JW, Zhuang X. (2003) Hyperdopaminergic Mutant Mice Have Higher "Wanting" But Not "Liking" for Sweet Rewards. The Journal of Neuroscience. 23. pp. 9395-9402.

Peixoto TC, Pietrobon CB, Bertasso IM, Caramez FAH, Calvino C, Santos TR, Oliveira E, Moura EG, Lisboa PC. (2020) Early weaning alters the thermogenic capacity of brown adipose tissue in adult male and female rats. European Journal of Nutrition. 59. pp. 2207-2218.

Pietrobon CB, Miranda RA, Bertasso IM, Mathias PCF, Bonfleur ML, Balbo SL, Reis MAB, Latorraca MQ, Arantes VC, de Oliveira E, Lisboa PC, de Moura EG. (2020) Early weaning induces short- and long-term effects on pancreatic islets in Wistar rats of both sexes. J Physiol. 598. pp. 489-502

Polidori C, de Caro G and Massi M. (2000) The hyperphagic effect of nociceptin/orphanin FQ in rats. Peptides. 2. pp. 1051- 1062.

Rudski JM, Billington CJ, Levine AS. (1994) Naloxone's effects on operant responding depend upon level of deprivation. Pharmacology Biochemistry and Behavior. 49. pp. 377-383.

Salas M, Torrero C, Rubio L, Regalado M. (2012) Effects of perinatal undernutrition on the development of neurons in the rat insular cortex. Nutritional Neuroscience. 15. pp. 20-25.

Shin AC, Pistell PJ, Phifer CB, Berthoud HR. (2010) Reversible suppression of food reward behavior by chronic mu-opioid receptor antagonism in the nucleus accumbens. Neuroscience. 170. pp. 580-588.

Silveira PP, Portella AK, Clemente Z, Bassani E, Tabajara AS, Gamaro GD, Dantas G, Torres IL, Lucion AB, Dalmaz C. (2004) Neonatal handling alters feeding behavior of adult rats. Physiology \& Behavior 80. pp.739-745.
Staszko SM, Boughter JD, Fletcher ML. (2020) Taste coding strategies in insular cortex. Experimental Biology and Medicine. 245. pp. 448-455.

Statnick MA, Chen Y, Ansonoff M, Witkin JM, Rorick-Kehn L, Suter TM, Song M, Hu C, Lafuente C, Jiménez A, Benito A, Diaz N, Martínez-Grau MA, Toledo MA, Pintar JE. (2016) A Novel Nociceptin Receptor Antagonist LY2940094 Inhibits Excessive Feeding Behavior in Rodents: A Possible Mechanism for the Treatment of Binge Eating Disorder. Journal of Pharmacology and Experimental Therapeutics. 356. pp. 493-502.

Teles Silva M, Mesquita da Silva K, Campos Rattes I, Maria Agostini Zonta G, Vasques da Costa A, Galvão Figueredo Costa R, Karen Cordeiro Nogueira L, Ogias D, Gama P. (2019) Immediate and Late Effects of Early Weaning on Rat Gastric Cell Differentiation. International Journal of Molecular Sciences. 21. pp. 196- 196.

Tepper BJ, Banni S, Melis M, Crnjar R, Tomassini Barbarossa I. (2014) Genetic sensitivity to the bitter taste of 6-n-propylthiouracil (PROP) and its association with physiological mechanisms controlling body mass index (BMI). Nutrients. 6. pp. 3363-81.

Welch CC, Grace MK, Billington CJ, Levine AS. (1994) Preference and diet type affect macronutrient selection after morphine, NPY, norepinephrine, and deprivation. Am J Physiol. 266. pp. R426-R433.

Witkin JM, Statnick MA, Rorick-Kehn LM, Pintar JE, Ansonoff M, Chen Y, Tucker RC, Ciccocioppo R. (2014) The biology of Nociceptin/Orphanin FQ (N/OFQ) related to obesity, stress, anxiety, mood, and drug dependence. Pharmacology \& Therapeutics. 141. pp. 283-299.

Yamamoto T. (2006) Neural substrates for the processing of cognitive and affective aspects of taste in the brain. Arch Histol Cytol. 69. pp. 243-55. 